\title{
PEMANFAATAN ABU BATUBARA SEBAGAI MATERIAL TANAH DASAR DI TAMBANG BATU HIJAU, SUMBAWA BARAT
}

\author{
Mara Maswahenu $^{1)}$, Firmansyah $^{2)}$, Aulya Salsabila $^{1)}$ \\ ${ }^{1)}$ Departemen Lingkungan, PT Amman Mineral Nusa Tenggara \\ ${ }^{2)}$ Departemen Dry Season Project, PT Amman Mineral Nusa Tenggara
}

\begin{abstract}
ABSTRAK
Pemanfaatan abu batubara (Fly Ash B409 dan Bottom Ash B410) yang sebelumnya dimanfaatkan oleh PT Amman Mineral Nusa Tenggara (PTAMNT) di tambang Batu Hijau sebagai substitusi semen dalam pembuatan beton hanya menyerap $1,7 \%$ dari total abu batubara yang dihasilkan. PLTU PTAMNT dapat menghasilkan \pm 1.000 ton abu batubara per bulan. Tujuan pemanfaatan abu batubara sebagai material campuran lapisan tanah dasar adalah meningkatkan penerapan prinsip $3 R$ limbah B3 secara internal (sampai dengan 100\%) dan mengurangi biaya perawatan dan perbaikan jalan dengan meningkatnya kualitas lapisan tanah dasar. Pada awal tahun 2018, PTAMNT telah memulai kajian pemanfaatan abu batubara sebagai bahan lapisan tanah dasar (road base) dan telah memperoleh izin pemanfataan abu batubara sebagai substitusi bahan baku tanah lapisan dasar (subgrade) sesuai Keputusan Menteri Lingkungan Hidup dan Kehutanan Nomor SK.337/Menlhk/Setjen/PLB.3/5/2019 tanggal 13 Mei 2019. Beberapa pengujian telah dilakukan sesuai persyaratan yang telah ditentukan dalam Peraturan Pemerintah Nomor 101 Tahun 2014 dan dalam izin pemanfaatan, termasuk diantaranya uji Toxicity Characteristic Leaching Procedure (TCLP), Loss on Ignition (LoI), Total Oksida Logam, uji California Bearing Ratio (CBR) laboratorium dengan berbagai komposisi pencampuran tanah dan abu batubara, serta uji aktivitas radionuklida. Hasil uji sampel campuran abu batubara menunjukan bahwa (1) semua hasil analisis TCLP berada di bawah baku mutu pada Lampiran III dan IV PP101 Tahun 2014, (2) nilai LoI sebesar 8,4\%, (3) nilai total oksida logam (penjumlahan $\mathrm{SiO}_{2}, \mathrm{Al}_{2} \mathrm{O}_{3}$, dan $\mathrm{Fe}_{2} \mathrm{O}_{3}$ ) sebesar 66,1\% (kelas C menurut ASTM C618012a dan SNI 2460:2014), (4) pencampuran tanah dengan abu batubara dapat menaikkan nilai CBR (4-18\%), dan (5) aktivitas radionuklida setiap parameter kurang dari $1 \mathrm{~Bq} / \mathrm{gram}$. Dinyatakan bahwa pencampuran abu batubara pada lapisan tanah dasar (road base) secara teknis dapat memberikan peningkatan kekuatan daya dukung tanah dasar dengan menaikkan hydraulic conductivity dan menurunkan permeabilitas tanah. Pemanfaatan ini (yang mana telah mendapatkan izin sesuai peraturan perundangan yang berlaku) dapat diaplikasikan pada jalan akses di area reklamasi timbunan batuan penutup dengan ketebalan 2.00 meter atau jalan umum di area sekitar Batu Hijau dengan ketebalan 0.50 meter. Komposisi abu batubara yang dicampurkan maksimal $50 \%$ dari berat total campuran tanah dasar
\end{abstract}

Keywords: Abu batubara, Limbah B3, pemanfaatan, 3R

\begin{abstract}
Coal ash utilization (Fly Ash B409 dan Bottom Ash B410) that has been conducted by PT Amman Mineral Nusa Tenggara (PTAMNT) in Batu Hijau Mine as cement substitute for concrete production was only be able to absorb $1.7 \%$ of the total coal ash produced. PTAMNT's Coal Power Plant can produce $\pm 1,000 \mathrm{~m}^{3}$ coal ash each month. The purposes of utilizing coal ash as road base material blend are to increase the principal application of hazardous waste $3 R$ internally (up to 100\%) and to reduce road maintenance and repair cost by increasing the road base quality. In the early 2018, PTAMNT has started the study to utilize coal ash as a road base material blend and acquired the permit based on The Decree of Minister of Environmental Affairs and Forestry Number SK.337/Menlhk/Setjen/PLB.3/5/2019 dated 13 May 2019. Several tests had been run according to the regulated requirements on Government Regulations Number 101 Year
\end{abstract}


2014, in which include Toxicity Characteristic Leaching Procedure (TCLP) test, Loss on Ignition (LoI), Total Metal Oxide, California Bearing Ratio (CBR) laboratory test with several composition of blend between soil and coal ash, and radionuclide activity test. The result of the given test showed that (1) all TCLP analysis were below the quality standards written on Attachment III and IV PP101 Year 2014, (2) LoI value of 8.4\%, (3) total metal oxide (addition of $\mathrm{SiO}_{2}, \mathrm{Al}_{2} \mathrm{O}_{3}$, dan $\mathrm{Fe}_{2} \mathrm{O}_{3}$ ) value of 66.1\% (class C according to ASTM C618012a and SNI 2460:2014), (4) increased CBR value (4-18\%) as a result of soil-coal ash blend, (5) radionuclide activity for each parameter is less than $1 \mathrm{~Bq} / \mathrm{gram}$. It is stated that coal ash blending on road base material can increase the strength capacity technically by increasing the hydraulic conductivity and reducing soil permeability. This utilization (which already obtained the permit pursuant to prevailing laws and regulations) can be applied on the access road of waste rock dump reclamation with 2,00 meter thickness or primary access road around Batu Hijau with 0.50 meter thickness. The maximum total composition of coal ash is $50 \%$ of the total weight of the road base.

Keywords: Coal Ash, Hazardous Waste, Utilization, 3R

\section{A. PENDAHULUAN}

PT Amman Mineral Nusa Tenggara (PTAMNT) mengoperasikan tambang Batu Hijau yang menghasilkan konsentrat tembaga dan emas di Kabupaten Sumbawa Barat, Provinsi Nusa Tenggara Barat, Indonesia. Untuk mendukung seluruh kegiatan pertambangan dan pengolahan mineral, dibutuhkan Pembangkit Listrik Tenaga Uap (PLTU) dengan kapasitas 4 x 28 MW yang berada di Area Pelabuhan Benete. Pada tahun 2018, PLTU dapat mengkonsumsi batubara jenis sub-bituminous dengan jumlah 585.455 ton per tahun atau \pm 1.800 ton per hari. Dengan konsumsi batubara sebesar nilai tersebut, PLTU Benete juga menghasilkan Abu Batubara yang terdiri dari abu terbang (fly ash) dengan kode limbah B409 dan abu dasar (bottom ash) dengan kode limbah B410. Jumlah produksi rata-rata abu batubara adalah \pm 12.000 ton per tahunnya. Pengelolaan limbah bahan berbahaya dan beracun (B3) abu batubara sebelumnya dilakukan dengan cara menimbun di tempat penimbunan sementara (landfill), pemanfaatan internal menjadi bahan campuran beton, dan pemanfaatan eksternal ke pihak ketiga. Pengelolaan dan pemanfaatan limbah B3 abu batubara oleh PTAMNT tersebut mengacu pada persyaratan dalam izin dan ketentuan perundang-undangan terkait.

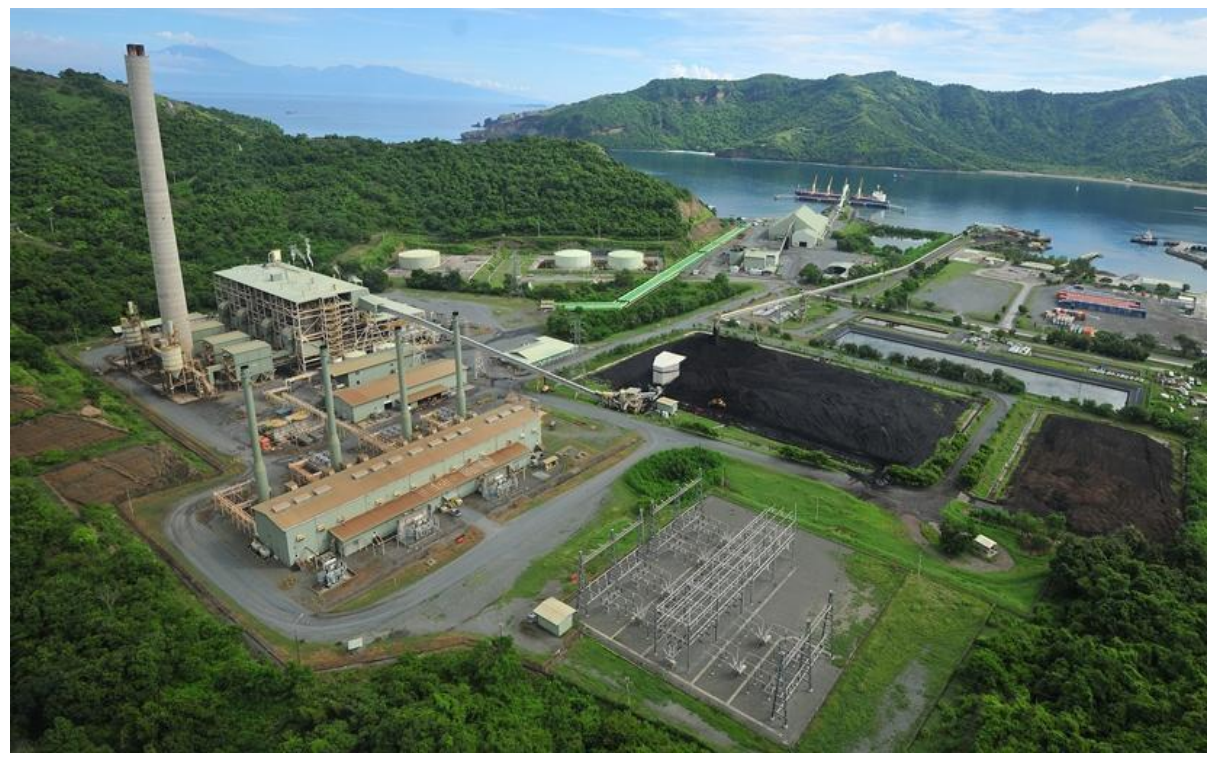

Gambar 1 - Area Pembangkit Listrik Benete milik PTAMNT

Data produksi, pemanfaatan, dan pengiriman abu batubara ke pihak ketiga disajikan pada Tabel 1. 
Tabel 1 - Produksi dan Pengelolaan Abu Batubara Tahun 2011 - 2018

\begin{tabular}{|c|c|c|c|c|c|c|c|c|}
\hline \multirow{3}{*}{ Tahun } & \multicolumn{3}{|c|}{ Produksi } & \multicolumn{5}{|c|}{ Pengelolaan } \\
\hline & \multirow{2}{*}{ Fly Ash } & \multirow{2}{*}{$\begin{array}{c}\text { Bottom } \\
\text { Ash }\end{array}$} & \multirow{2}{*}{$\begin{array}{c}\text { Abu } \\
\text { Batubara }\end{array}$} & \multicolumn{2}{|c|}{ Pemanfaatan Internal } & \multicolumn{2}{|c|}{ Pemanfaatan Eksternal } & \multirow{2}{*}{$\begin{array}{c}\text { Volume } \\
\text { Sisa dalam } \\
\text { Landfill }\end{array}$} \\
\hline & & & & Total & $\%$ & Total & $\%$ & \\
\hline 2011 & $7,694.96$ & $1,926.31$ & $9,621.27$ & - & $0.00 \%$ & $15,121.00$ & $65.91 \%$ & $7,822.27$ \\
\hline 2012 & $9,640.15$ & $2,411.45$ & $12,051.60$ & - & $0.00 \%$ & $1,472.40$ & $12.22 \%$ & $10,579.20$ \\
\hline 2013 & $9,475.20$ & $2,374.27$ & $11,849.47$ & - & $0.00 \%$ & $19,029.33$ & $63.70 \%$ & $10,842.12$ \\
\hline 2014 & $7,392.07$ & $1,856.96$ & $9,249.03$ & - & $0.00 \%$ & $15,274.05$ & $62.28 \%$ & $9,249.03$ \\
\hline 2015 & $9,124.87$ & $2,244.15$ & $11,369.02$ & 152.97 & $0.58 \%$ & $14,956.98$ & $56.49 \%$ & $11,369.02$ \\
\hline 2016 & $12,347.93$ & $3,083.66$ & $15,431.59$ & $1,110.78$ & $4.16 \%$ & $15,034.00$ & $56.30 \%$ & $10,560.16$ \\
\hline 2017 & $13,050.13$ & $3,262.53$ & $16,312.66$ & - & $0.00 \%$ & - & $0.00 \%$ & $22,918.72$ \\
\hline 2018 & $10,553.56$ & $2,638.34$ & $13,191.90$ & $3,647.05$ & $11.94 \%$ & $22,367.90$ & $73.25 \%$ & $4,521.07$ \\
\hline Rerata & $9,909.86$ & $2,474.71$ & $12,384.57$ & 613.85 & $2.09 \%$ & $12,906.96$ & $48.77 \%$ & $10,982.70$ \\
\hline
\end{tabular}

Keterangan: (1) Angka dalam m³ ; (2) Produksi Fly Ash dan Bottom Ash diperoleh dari spesifikasi batubara dalam sertifikat pengiriman; (3) Produksi abu batubara diperoleh dari penjumlahan Fly Ash dan Bottom Ash; (4) Jumlah abu batubara yang dimanfaatkan internal diperoleh dari perhitungan pemanfaatan; (5) Jumlah abu batubara yang dimanfaatkan eksternal dan sisa volume landfill diperoleh dari hasil survei.

Dari tabel 1 dapat diketahui bahwa rerata pertahun pengelolaan limbah B3 abu batubara secara pemanfaatan internal hanya mencakup 2,09\% dalam kurun waktu delapan tahun terakhir. Dengan informasi inilah, perlu dicari cara untuk dapat memanfatkan limbah B3 abu batubara dengan persentase yang lebih besar secara internal. Pemanfaatan abu batubara sebagai campuran lapisan tanah dasar (sub grade) adalah salah satunya yang juga sejalan dengan lingkup penggunaan abu batubara dalam Dokumen Andal PLTU PT Newmont Nusa Tenggara (PTNNT) tahun 1997 yang menyatakan bahwa penggunaan kembali abu batubara mencakup reklamasi sebagai bahan untuk meningkatkan tanah pertanian, bahan penetral lokal untuk timbunan, dan pengendali $\mathrm{pH}$ di pengolahan tambang (PTNNT, 1997).

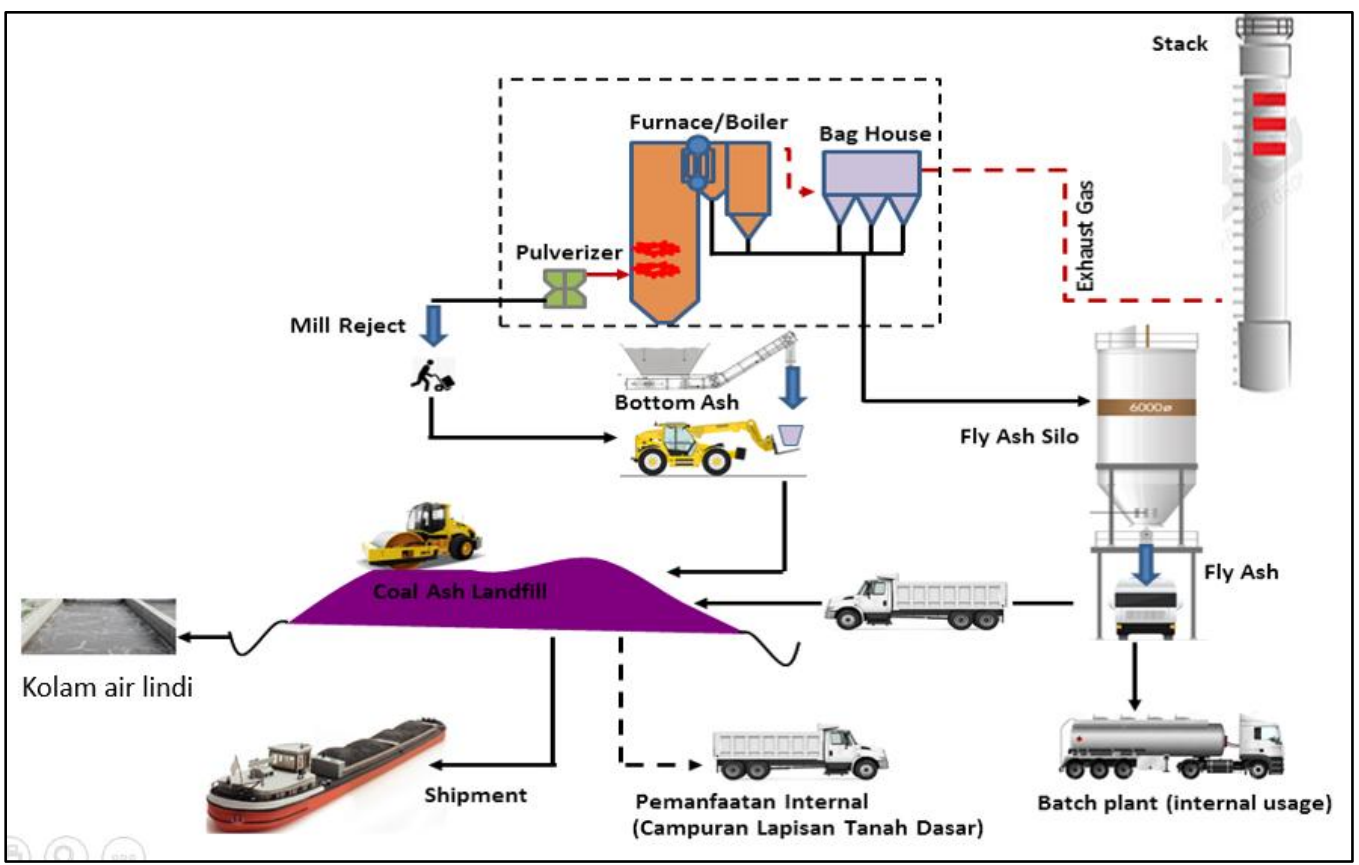

Gambar 2 - Bagan Alir Pengelolaan Abu Batubara 


\section{B. TUJUAN DAN METODE}

Tujuan pemanfaatan abu batubara sebagai campuran lapisan tanah dasar (sub grade) adalah penerapan prinsip 3R (reduce, reuse, recycle) terhadap limbah $\mathrm{B} 3$ abu batubara dengan meningkatkan kemanfaatan limbah B3 sebagai bahan baku secara internal (sampai dengan 100\%) dan mengurangi biaya perawatan dan perbaikan jalan dengan meningkatnya kualitas lapisan tanah dasar setelah memanfaatkan abu batubara.

Kajian dan pemanfaatan abu batubara sebagai campuran lapisan tanah dasar sudah kerap dilakukan dengan mengacu pada karakteristik fisik dan kimiawi abu batubara yang (1) memiliki ukuran parikel yang kecil, (2) mempunyai sifat pozzolanic dan cementitious, dan (3) kandungan silika dan kalsium yang tinggi. Tulisan ini akan meneliti dan membahas kandungan abu batubara yang dimiliki PTAMNT, apakah sesuai untuk dimanfaatkan sebagai yang disebutkan, dengan mengacu kepada:

1. Uji Nilai Total Oksida Logam dan klasifikasi kelas Abu Batubara sesuai ASTM C618-12a dan SNI 2460:2014;

2. Uji Toxicity Characteristic Leaching Procedure (TCLP) sesuai Lampiran III dan IV, PP No.101 Tahun 2014;

3. Uji Loss on Ignition (LoI)

4. Uji Nilai California Bearing Ratio (CBR) dengan perbandingan campuran komposisi abu batubara dan tanah (mak. campuran komposisi 50 abu batubara : 50 tanah); dan

5. Uji Aktifitas Radionuklida sesuai metode pengujian IAEA Technical Report Series No, 295/SNI ISO 10703.2009

\section{HASIL DAN PEMBAHASAN}

\section{C.1. Uji Nilai Total Oksida Logam}

Menurut ASTM C618 abu terbang dibagi menjadi tiga kelas, yaitu kelas F, C, dan N. Perbedaan utama dari masing-masing kelas adalah banyaknya kalsium, silika, aluminium, dan kadar besi.

Tabel 2 - Kelas Abu Terbang dan Keterangannya.

\begin{tabular}{|c|c|c|}
\hline $\begin{array}{c}\text { Kelas } \\
\text { Abu Terbang }\end{array}$ & Keterangan & Persyaratan \\
\hline $\mathrm{F}$ & $\begin{array}{l}\text { Dihasilkan dari pembakaran batubara anthracite } \\
\text { atau bituminous, mempunyai sifat pozzolanic dan } \\
\text { untuk mendapatkan sifat cementitious harus diberi } \\
\text { penambahan quick lime, hydrated lime, atau semen. }\end{array}$ & $\begin{array}{c}\mathrm{SiO}_{2}+\mathrm{Al}_{2} \mathrm{O}_{3}+\mathrm{Fe}_{2} \mathrm{O}_{3} \geq 70 \% \\
\mathrm{CaO}<10 \%\end{array}$ \\
\hline $\mathrm{C}$ & $\begin{array}{l}\text { Dihasilkan dari pembakaran batubara lignite dan } \\
\text { sub-bituminous selain mempunyai sifat pozzolanic } \\
\text { juga mempunyai sifat self-cementing (kemampuan } \\
\text { untuk mengeras dan menambah kekuatan apabila } \\
\text { bereaksi dengan air) dan sifat ini timbul tanpa } \\
\text { penambahan kapur. }\end{array}$ & $\begin{array}{c}\mathrm{SiO}_{2}+\mathrm{Al}_{2} \mathrm{O}_{3}+\mathrm{Fe}_{2} \mathrm{O}_{3} \geq 50 \% \\
\mathrm{CaO}>10 \%\end{array}$ \\
\hline $\mathrm{N}$ & $\begin{array}{l}\text { Kadar kapur } \mathrm{CaO}>20 \% \\
\text { Pozzolan alam atau pozzolan yang telah di } \\
\text { kalsinasi. Selain itu juga hasil berbagai pembakaran } \\
\text { yang mempunyai sifat pozzolan yang baik. }\end{array}$ & $\mathrm{SiO}_{2}+\mathrm{Al}_{2} \mathrm{O}_{3}+\mathrm{Fe}_{2} \mathrm{O}_{3} \geq 70 \%$ \\
\hline
\end{tabular}

Hasil pengujian pada Tabel 3 di bawah, yang dilakukan oleh laboratorium eksternal menunjukan hasil penjumlahan kadar silika, alumunium, dan besi pada abu terbang dan abu batubara PTAMNT kurang dari $70 \%$, sehingga digolongkan sebagai kelas C. Dengan tergolongnya abu batubara 
PTAMNT sebagai kelas C, tidak perlu ditambahkannya material lain untuk membuatnya mempunyai sifat cementitious pada kegiatan pemanfaatan yang dimaksud.

Tabel 3 - Hasil Laboratorium Kelas Abu Batubara PTAMNT (ASTM C618)

\begin{tabular}{lccc}
\hline \multicolumn{1}{c}{ Uji Total Oksida Logam } & Unit & Abu Terbang & Abu Batubara \\
\hline Alumunium $\mathrm{Oxide}, \boldsymbol{A l}_{\mathbf{2}} \boldsymbol{O}_{\mathbf{3}}$ & $\%$ & 11,6 & 11,2 \\
Calcium Oxide, $\boldsymbol{C a O}$ & $\%$ & 15,6 & 13,6 \\
Iron Oxide, $\mathbf{F e}_{\mathbf{2}} \boldsymbol{O}_{\mathbf{3}}$ & $\%$ & 24,8 & 21,6 \\
Silicon Oxide, $\mathbf{S i O}_{\mathbf{2}}$ & $\%$ & 33,2 & 33,3 \\
Penjumlahan $\mathbf{S i O}_{\mathbf{2}}+\boldsymbol{A l}_{\mathbf{2}} \boldsymbol{O}_{\mathbf{3}}+\boldsymbol{F e}_{\mathbf{2}} \boldsymbol{O}_{\mathbf{3}}$ & $\%$ & 69,6 & 66,1 \\
Kelas Abu (sesuai ASTM C618) & & $\mathbf{C}$ & C \\
\hline
\end{tabular}

\section{C.2. Uji TCLP}

Hasil analisa uji TCLP yang telah dilakukan terhadap abu batubara PTAMNT di laboratorium eksternal terakreditasi menunjukkan bahwa semua hasil analisanya berada di bawah baku mutu pada Lampiran III PP No. 101 Tahun 2014 tentang Baku Mutu Karakteristik Beracun Melalui TCLP untuk Penetapan Kategori Limbah B3 maupun Lampiran IV PP No. 101 Tahun 2014 tentang Baku Mutu Karakteristik Beracun melalui TCLP untuk Penetapan Standar Pengolahan Limbah Bahan Berbahaya dan Beracun Sebelum Ditempatkan di Fasilitas Penimbunan Akhir.

Hasil analisa TCLP untuk semua jenis logam yang berada dibawah baku mutu mengindikasikan bahwa abu batubara PTAMNT pada dasarnya tidak memiliki karakteristik yang beracun.

Tabel 4 - Hasil Uji Analisa TCLP Abu Batubara PTAMNT

\begin{tabular}{|c|c|c|c|c|c|c|c|c|c|}
\hline \multicolumn{2}{|c|}{ Pengelompokan Analit } & Unit & $\mathrm{DL}$ & $\begin{array}{c}\text { Abu Terbang } \\
\text { 27-Oct-17 } \\
\text { Hasil Uji }\end{array}$ & $\begin{array}{c}\text { Abu Dasar } \\
\text { 27-Oct-17 } \\
\text { Hasil Uji }\end{array}$ & $\begin{array}{c}\text { Abu Batubara } \\
\text { 27-Oct-17 } \\
\text { Hasil Uji }\end{array}$ & $\begin{array}{c}\text { PP 101/2014 } \\
\text { TCLP A } \\
\text { (Lamp. III) }\end{array}$ & $\begin{array}{c}\text { PP 101/2014 } \\
\text { TCLP B } \\
\text { (Lamp. III) }\end{array}$ & $\begin{array}{c}\text { PP 101/2014 } \\
\text { TCLP } \\
\text { (Lamp. IV) }\end{array}$ \\
\hline \multicolumn{10}{|l|}{ Logam TCLP } \\
\hline Chromium-Hexavalent & Cr6+ & $\mathrm{mg} / \mathrm{L}$ & 1 & $<1$ & $<1$ & $<1$ & 15 & 2.5 & 2.5 \\
\hline Mercury & $\mathrm{Hg}$ & $\mathrm{mg} / \mathrm{L}$ & 0.001 & $<0,001$ & $<0,001$ & $<0,001$ & 0.3 & 0.05 & 0.05 \\
\hline Silver & $\mathrm{Ag}$ & $\mathrm{mg} / \mathrm{L}$ & 0.2 & $<0,2$ & $<0,2$ & $<0,2$ & 40 & 5 & 5 \\
\hline Arsenic & As & $\mathrm{mg} / \mathrm{L}$ & 0.05 & $<0,05$ & $<0,05$ & $<0,05$ & 3 & 0.6 & 0.5 \\
\hline Barium & $\mathrm{Ba}$ & $\mathrm{mg} / \mathrm{L}$ & 1 & 1 & 2 & 1 & 210 & 35 & 35 \\
\hline Berylium & $\mathrm{Be}$ & $\mathrm{mg} / \mathrm{L}$ & 0.05 & $<0,05$ & $<0,05$ & $<0,05$ & 4 & 0.5 & 0.5 \\
\hline Boron & B & $\mathrm{mg} / \mathrm{L}$ & 20 & $<20$ & $<20$ & $<20$ & 150 & 25 & 25 \\
\hline Cadmium & $\mathrm{Cd}$ & $\mathrm{mg} / \mathrm{L}$ & 0.05 & $<0,05$ & $<0,05$ & $<0,05$ & 0.9 & 0.15 & 0.15 \\
\hline Chromium & $\mathrm{Cr}$ & $\mathrm{mg} / \mathrm{L}$ & 0.5 & $<0,5$ & $<0,5$ & $<0,5$ & - & - & - \\
\hline Copper & $\mathrm{Cu}$ & $\mathrm{mg} / \mathrm{L}$ & 0.1 & $<0,1$ & $<0,1$ & $<0,1$ & 60 & 10 & 10 \\
\hline Lead & $\mathrm{Pb}$ & $\mathrm{mg} / \mathrm{L}$ & 0.5 & $<0,5$ & $<0,5$ & $<0,5$ & 3 & 0.5 & 0.5 \\
\hline Molybdenum & Mo & $\mathrm{mg} / \mathrm{L}$ & 0.05 & 0.09 & $<0,05$ & $<0.05$ & 21 & 3.5 & 3.5 \\
\hline Nickel & $\mathrm{Ni}$ & $\mathrm{mg} / \mathrm{L}$ & 0.05 & $<0,05$ & $<0,05$ & 0.17 & 21 & 3.5 & 3.5 \\
\hline Selenium & $\mathrm{Se}$ & $\mathrm{mg} / \mathrm{L}$ & 0.05 & 0.07 & $<0,05$ & $<0.05$ & 3 & 0.5 & 3.5 \\
\hline Antimony & $\mathrm{Sb}$ & $\mathrm{mg} / \mathrm{L}$ & 0.01 & $<0.01$ & $<0.01$ & 0.01 & 6 & 1 & 1 \\
\hline Zinc & $\mathrm{Zn}$ & $\mathrm{mg} / \mathrm{L}$ & 0.05 & $<0,05$ & 0.8 & 0.36 & 300 & 50 & 50 \\
\hline
\end{tabular}

(Sumber: Laboratorium Eksternal; Lampiran III dan IV, PP No. 101 Tahun 2014)

Hasil uji TCLP abu batubara yang jauh dibawah baku mutu yang ditetapkan dalam PP 101/2014

\section{C.3. Uji LoI}

Hasil analisa Uji LoI yang telah dilakukan terhadap abu batubara PTAMNT di laboratorium eksternal terakreditas menunjukkan bahwa dengan mencampur abu terbang dengan abu dasar menghasilkan nilai LoI yang tidak signifikan (dibawah 10\%) yang menjadikan material tersebut telah melalui perubahan massa secara utuh. Dapat dibandingkan dengan nilai LoI pada abu dasar, $29,6 \%$, yang mengindikasikan bahwa material tersebut masih dapat melalui perubahan massa karena pembakaran yang tidak sempurna pada tahap pembakaran batubara di boiler PLTU. 
Tabel 5 - Hasil Uji Loss on Ignition (LoI) Abu Batubara PTAMNT

\begin{tabular}{lccc}
\hline \multicolumn{1}{c}{$\begin{array}{c}\text { Jenis } \\
\text { Sampel }\end{array}$} & $\begin{array}{c}\text { Tanggal } \\
\text { Sampel }\end{array}$ & Unit & $\begin{array}{c}\text { Loss on } \\
\text { Ignition } \\
\text { (Lol) }\end{array}$ \\
\hline Abu Terbang & 02-Nov-17 & \% kering & 2.8 \\
Abu Dasar & 02-Nov-17 & \% kering & 29.6 \\
Abu Batubara & 02-Nov-17 & \% kering & 8.4 \\
\hline
\end{tabular}

(Sumber: Laboratorium Eksternal)

\section{C.4. Uji Nilai CBR}

Dalam pemanfaatan abu batubara tentunya diperlukan pengujian teknis untuk memperoleh data dan informasi parameter sifat fisik dan mekanik pencampuran abu batubara pada lapisan tanah dasar. Hasil pengujian yang dilakukan dapat digunakan untuk menentukan persentase abu batubara dan tanah dasar yang paling optimum untuk memberikan kekuatan daya dukung tanah berdasarkan nilai CBR.

Pengujian laboratorium menggunakan standar acuan sebagai berikut:

Tabel 6 - Jenis Pengujian dan Standar Acuan Campuran Abu Batubara dan Tanah Dasar PTAMNT

\begin{tabular}{clr}
\hline No. & \multicolumn{1}{c}{ Jenis Pengujian } & Standar Pengujian \\
\hline 1 & Metode pengujian kepadatan berat untuh tanah & SNI 1743:2008 \\
2 & Metode pengujian batas cair & SNI 1967:2008 \\
3 & Metode pengujian batas plastis & SNI 1966:2008 \\
4 & Metode pengujian CBR laboratorium & SNI 1744:2012 \\
5 & $\begin{array}{l}\text { Metode pengujian tentang analisis saringan agregat halus dan } \\
\text { kasar }\end{array}$ & SNI ASTM C136:2012 \\
6 & Metode pengujian keausan agregat dengan mesin abrasi Los & SNI 2417:2008 \\
& Angeles & SNI 03-4141:1996 \\
7 & $\begin{array}{l}\text { Metode pengujian gumpalan lempung dan butir-butir mudah } \\
\text { pecah dalam agregat }\end{array}$ & SNI 1969:2008 \\
8 & Metode pengujian berat jenis gabungan & SNI 1742:2008 \\
\hline
\end{tabular}

Sampel abu batubara dan tanah dasar dengan berbagai komposisi dikirimkan ke laboratorium eksternal terakreditasi untuk pengujian CBR, Hasil pengujian CBR disajikan pada tabel 8 sebagai berikut:

Tabel 7 - Hasil Uji CBR pada Komposisi Campuran Tanah : Abu Batubara

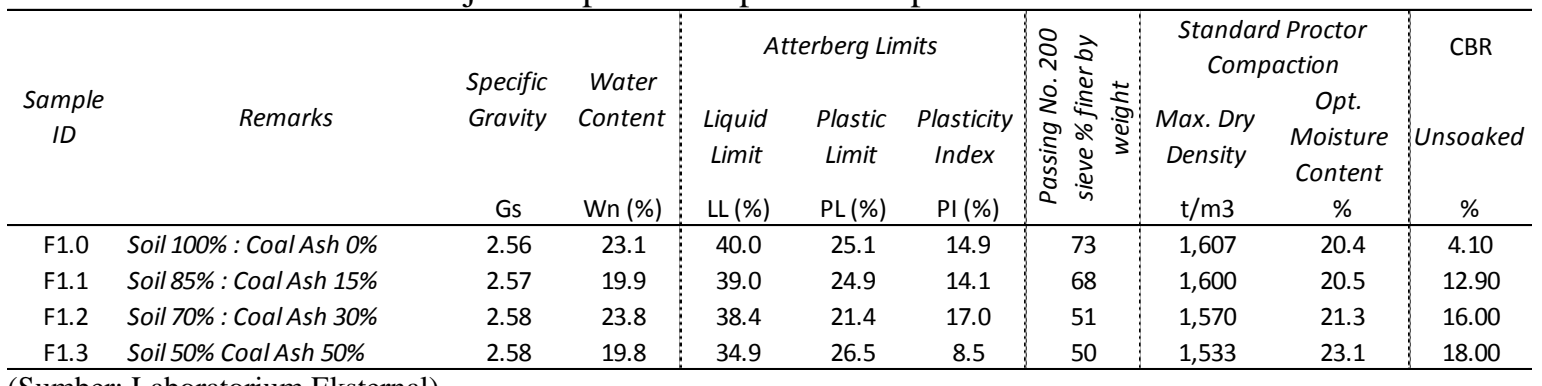

(Sumber: Laboratorium Eksternal)

Hasil pengujian CBR laboratorium menunjukan nilai CBR pada tanah tanpa campuran (F1.0) sebesar $4,10 \%$, nilai CBR naik menjadi $12,90 \%$ pada komposisi pencampuran abu batubara $15 \%$ : tanah $85 \%$ (F1.1), dan nilai CBR naik menjadi 18\% pada komposisi pencampuran 50\%: $50 \%$ (F1.3). Dengan demikian dapat dinyatakan bahwa pencampuran abu batubara dengan tanah berkorelasi positif dengan kenaikan nilai CBR dan pada komposisi pencampuran 50\% abu batubara dan 50\% tanah, nilai CBR naik menjadi 18,00. Hasil uji CBR ini sesuai dengan hasil penelitian 
yang dilakukan oleh Gunawan, G dan Fransisko, S (2011) yang menyatakan pencampuran abu terbang dengan tanah sebesar 15\% dan 20\% dapat meningkatkan nilai CBR secara berurutan sebesar $132 \%$ dan 209\% dan oleh Malik et.al (2015) yang menyatakan pencampuran dengan abu batubara sebesar 30\% mampu menaikkan nilai CBR tanah sebanyak 28,5\%.

Penambahan abu batubara juga mampu menstabilisasi tanah ekspansif dengan menurunkan indeks plastisitas (Budi, G.S et.al, 2003). Hasil uji batas-batas konsistensi Atterberg menunjukkan pencampuran tanah dengan abu batubara mampu memperbaiki sifat tanah. Pada komposisi pencampuran $50 \%$, nilai batas cair (liquid limit) turun menjadi 34,9\% dan indeks plastistitas (plasticity index) turun menjadi 8,50\%.

\section{C.5. Uji Radionuklida}

Hasil analisa uji radionuklida yang telah dilakukan terhadap abu batubara PTAMNT di laboratorium eksternal terakreditasi menunjukkan bahwa konsentrasi aktivitas semuanya dibawah $1 \mathrm{~Bq} / \mathrm{gr}$ (becquerel per gram) atau berada di bawah baku mutu seperti yang telah ditetapkan sesuai Keputusan Menteri Lingkungan Hidup dan Kehutanan Republik Indonesia Nomor SK. 337/Menlhk/Setjen/PLB.3/5/2019 Tentang Izin Pengelolaan Limbah Bahan Berbahaya dan Beracun Untuk Kegiatan Pemanfaatan Limbah Bahan Berbahaya dan Beracun PT Amman Mineral Nusa Tenggara sebagai Penghasil Limbah Bahan Berbahaya dan Beracun.

Tabel 8 - Hasil Uji Radionuklida Abu Batubara PTAMNT

\begin{tabular}{|c|c|c|c|c|c|c|c|}
\hline \multirow{2}{*}{ No } & \multirow{2}{*}{ Radioactivity } & \multirow{2}{*}{ Metode Pengujian } & \multirow{2}{*}{ Satuan } & \multirow{2}{*}{$\begin{array}{l}\text { Baku Mutu } \\
\text { Sesuai Ijin }\end{array}$} & \multirow{2}{*}{$\begin{array}{l}\text { Limit of } \\
\text { Reporting }\end{array}$} & \multicolumn{2}{|c|}{ Hasil Pengujian } \\
\hline & & & & & & Abu Terbang & Abu Dasar \\
\hline 1 & ${ }^{210} \mathrm{~Pb}$ & $\begin{array}{l}\text { IAEA Technical Report Series } \\
\text { No. } 295 / \text { SNI ISO } 10703.2009\end{array}$ & $\mathrm{~Bq} / \mathrm{g}$ & $>1$ & $<0.0001$ & 0.0013 & $<0.0001$ \\
\hline 2 & ${ }^{226} \mathrm{Ra}$ & $\begin{array}{l}\text { IAEA Technical Report Series } \\
\text { No. } 295 / \text { SNI ISO } 10703.2010\end{array}$ & $\mathrm{~Bq} / \mathrm{g}$ & $>1$ & $<0.001$ & 0.0278 & 0.0161 \\
\hline 3 & ${ }^{228} \mathrm{Ra}$ & $\begin{array}{l}\text { IAEA Technical Report Series } \\
\text { No. } 295 / \text { SNI ISO 10703.2011 }\end{array}$ & $\mathrm{Bq} / \mathrm{g}$ & $>1$ & $<0.001$ & 0.0248 & 0.009 \\
\hline 4 & ${ }^{228} \mathrm{Th}$ & $\begin{array}{l}\text { IAEA Technical Report Series } \\
\text { No. } 295 / \text { SNI ISO } 10703.2012\end{array}$ & $\mathrm{~Bq} / \mathrm{g}$ & $>1$ & $<0.001$ & 0.0248 & 0.0113 \\
\hline 5 & ${ }^{230} \mathrm{Th}$ & $\begin{array}{l}\text { IAEA Technical Report Series } \\
\text { No. } 295 / \text { SNI ISO 10703.2013 }\end{array}$ & $\mathrm{Bq} / \mathrm{g}$ & $>1$ & $<0.001$ & $<0.001$ & $<0.001$ \\
\hline 6 & ${ }^{234} \mathrm{Th}$ & $\begin{array}{l}\text { IAEA Technical Report Series } \\
\text { No. } 295 / \text { SNI ISO 10703.2014 }\end{array}$ & $\mathrm{Bq} / \mathrm{g}$ & $>1$ & $<0.0001$ & 0.0029 & $<0.0001$ \\
\hline 7 & ${ }^{238} \mathrm{U}$ & $\begin{array}{l}\text { IAEA Technical Report Series } \\
\text { No. } 295 / \text { SNI ISO } 10703.2015\end{array}$ & $\mathrm{~Bq} / \mathrm{g}$ & $>1$ & $<0.001$ & $<0.001$ & $<0.001$ \\
\hline
\end{tabular}

(Sumber: Laboratorium Eksternal)

\section{C.6. Volume Produksi dan Volume Pemanfaatan Internal}

Seperti yang telah diketahui PLTU Benete dapat menghasilkan abu batubara sebanyak 12.000 ton per tahunnya. Untuk melaksanakan pemanfaatan internal sebanyak 100\%, pemanfaatan limbah B3 abu batubara sebagai campuran lapisan tanah dasar harus dioptimalkan dengan mempertimbangkan luas area, ketebalan, dan komposisi volume pemanfaatan, serta volume landfill abu batubara. Dengan merujuk kepada prosedur standar kerja PTAMNT dengan nomor: CDC-MIN-032-G102 berjudul $2 H 1 V$ Construced Fill Reclamation Slopes yang menginstruksikan ketebalan material 
subgrade setebal 2,00 meter, volume abu batubara yang dapat dimanfaatkan tersajikan pada Tabel 9.

Tabel 9 - Volume Abu Batubara yang dapat dimanfaatkan secara Internal

\begin{tabular}{ccccccc} 
Tahun & $\begin{array}{c}\text { Volume Landfill } \\
\text { Awal Tahun }\end{array}$ & $\begin{array}{c}\text { Produksi } \\
\text { per tahun }\end{array}$ & \multicolumn{2}{c}{ Pemanfaatan } & $\begin{array}{c}\text { Persentase } \\
\text { Beton }\end{array}$ & $\begin{array}{c}\text { Campuran } \\
\text { tanah dasar }\end{array}$ \\
Pemanfaatan & Akhir Tahun \\
\hline 2019 & 11.788 & 12.000 & 1.000 & 17.000 & 76 & 17.339 \\
2020 & 5.788 & 12.000 & 1.000 & 15.000 & 90 & 13.339 \\
2021 & 1.788 & 12.000 & 1.000 & 12.000 & 94 & 9.339 \\
2022 & 788 & 12.000 & 1.000 & 11.000 & 94 & 5.339 \\
2023 & 788 & 12.000 & 1.000 & 11.000 & 94 & 1.339 \\
\hline
\end{tabular}

\section{KESIMPULAN}

Dengan melihat keadaan lapangan di Batu Hijau, pemanfaatan abu batubara sebagai material tanah dasar dapat menyerap 94\% dari total abu batubara yang dihasilkan oleh PLTU Benete dan pemanfaatan abu batubara sebagai bahan campuran beton yang telah dilaksanakan.

Hasil uji sampel campuran abu batubara menunjukan bahwa (1) semua hasil analisis TCLP berada di bawah baku mutu pada Lampiran III dan IV PP101 Tahun 2014, (2) nilai LoI sebesar 8,4\%, (3) nilai total oksida logam (penjumlahan $\mathrm{SiO}_{2}, \mathrm{Al}_{2} \mathrm{O}_{3}$, dan $\mathrm{Fe}_{2} \mathrm{O}_{3}$ ) sebesar $66,1 \%$ (kelas $\mathrm{C}$ menurut ASTM C618012a dan SNI 2460:2014), (4) pencampuran tanah dengan abu batubara dapat menaikkan nilai CBR (maks. 18\% dengan komposisi 50:50), dan (5) konsentrasi aktivitas radionuklida Uranium-238 (U-238), Plumbum-210 (Pb-210), Radium-226 (ra-226), Radium-228 (Ra-228), Thorium-228 (Th-228), Thorium-230 (Th-230) dan Thorium-234 (Th-234) jauh dibawah baku mutu yang diijinkan yaitu $1 \mathrm{~Bq} / \mathrm{gram}$.

\section{DAFTAR PUSTAKA}

Amman Mineral Nusa Tenggara, PT. (2018). Proposal Pemanfaatan Abu Batubara Sebagai Campuran Lapisan Tanah Dasar di Tambang Batu Hijau, Februari 2018.

Anonim (2006). Pekerjaan Lapis Pondasi Jalan Buku 3 Lapis Pondasi Agregat. Manual Konstruksi dan Bangunan No : 002-03/BM/2006. Departemen Pekerjaan Umum Direktorat jenderal Bina Marga. .

Anonim (2006). Pekerjaan Tanah Dasar Buku 3. Pedoman penyelidikan dan pengujian tanah dasar untuk pekerjaan jalan. Pedoman Konstruksi dan Bangunan. No: 003-03/BM/2006. Departemen Pekerjaan Umum Direktorat Jenderal Bina Marga.

Budi, G.S, Cristanto A, Setiawan E. (2003). Pengaruh fly ash terhadap sifat pengembangan tanah ekspansif. Civil Engineering Dimension, Vol. 5, No. 1, 20-24, March 2003.

G. Gunawan, Silverster Fransisko. Pemanfaatan limbah abu terbang yang ramah lingkungan sebagai bahan stabilisasi tanah dasar. Puslitbang Jalan dan Jembatan, August 2011

Malik M.I., Iqbal A, Mansoor J., Nazir H, Iqbal T. Effect of coal ash on strength and CBR properties of lacustrine soil. International Journal of Engineering Research \& Technology (IJERT) ISSN : 2278-0181 Vol. 4 Issue 03, March 2015.

Spesifikasi Umum Bidang Jalan dan Jembatan (PUSJATAN). "Pemberlakuan Pedoman Pelaksanaan Stabilisasi Bahan Jalan Langsung Di Tempat Dengan Bahan Serbuk Pengikat No.01/SE/M/2010" 